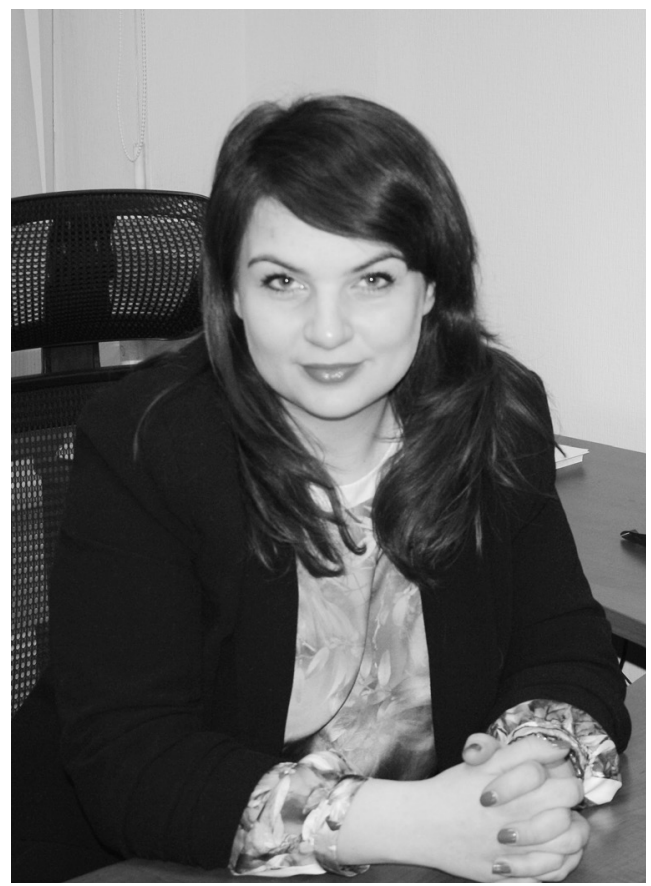

marusheva.o@gmail.com

\section{UDC:351}

DOI: https://doi.org/10.32689/2617-

2224-2019-4(19)-156-165

\section{Марушева Олександра Анатоліївна,} кандидат юридичних наук, доцент кафедри публічного адміністрування, здобувач наукового ступеня доктора наук з державного управління, Міжрегіональна Академія управління персоналом, 03039, м. Київ, вул. Фрометівська, 2, тел.: +38 (067)89594 85,e-mail: marusheva.o@ gmail.com

ORCID: 0000-0001-9126-4674

Марушева Александра Анатольевна, кандидат юридических наук, доцент кафедры публичного администрирования, соискатель научной степени доктора наук по государственному управлению, Межрегиональная Академия управления персоналом, 03039, г. Киев, ул. Фрометовская, 2, тел.: +38 (067) 89594 85, e-mail:

ORCID: 0000-0001-9126-4674

Marusheva Oleksandra Anatoliivna,

PhD in Law, Associate Professor of the Department of Public Administration, Doctoral research scholar of the Department of Public Administration; Interregional Academy of Personnel Management, 03039, Kyiv, Str. Frometivska, 2, tel.: +38 (067) 89594 85, e-mail: marusheva.o@gmail.com

\title{
ОСОБЛИВОСТІ НОРМАТИВНО-ПРАВОВОГО РЕГУЛЮВАННЯ СОЦІАЛЬНО-ЕКОНОМІЧНИХ ВІДНОСИН У БУДІВНИЦТВІ: ЗАРУБІЖНИЙ АСПЕКТ
}

Анотація. Розкрито зарубіжний аспект особливостей нормативно-правового регулювання соціально-економічних відносин у будівництві. Зазначено, що сучасна економіка України перебуває у стані хронічної кризи, тому цікаво проаналізувати досвід будівництва США, Канади та країн Свропейського Союзу з точки зору встановлення нормативно-правового механізму управління соціально-економічними відносинами у будівництві. Обгрунтовано, що у США особливістю державного управління нормативно-пра- 
вовим регулюванням соціально-економічних відносин у будівництві є розроблення власного нормативно-правового механізму та системи контролю за дотриманням відповідних законодавчих вимог. 3 цією метою відбулося прийняття відповідних кодексів, законодавчих актів у сферах будівництва та іпотечного кредитування, надання пільгових кредитів, гарантій, забезпечення дієвих механізмів системи страхування тощо.

Визначено, що у більшості зарубіжних країн спостерігається тенденція “приватизаціï” функцій нагляду та контролю за дотриманням вимог будівельного законодавства, органів та організацій, відповідальних за функціонування системи технічного регулювання у будівництві тощо. Причини цього - ускладнення та вдосконалення будівельних технологій, збільшення обсягів будівництва та перехід багатьох країн світу до використання параметричних норм.

Доведено, що світовий досвід впровадження архітектурно-будівельного контролю у зарубіжних країнах є необхідною основою для вдосконалення національної державної системи будівництва. Включення до системи нагляду та контролю незалежних приватних спеціалізованих установ або експертів до виконання функцій контролю не тільки покращить якість заходів контролю, але й знизить рівень корупції у будівельній сфері.

Ключові слова: державне управління, соціально-економічні відносини, будівництво, нормативно-правове регулювання, механізм, зарубіжний досвід, архітектурно-будівельний контроль, нормування в будівництві.

\section{ОСОБЕННОСТИ НОРМАТИВНО-ПРАВОВОГО РЕГУЛИРОВАНИЯ СОЦИАЛЬНО-ЭКОНОМИЧЕСКИХ ОТНОШЕНИЙ В СТРОИТЕЛЬСТВЕ: ЗАРУБЕЖНЫЙ АСПЕКТ}

Аннотация. Раскрыт зарубежный аспект особенностей нормативно-правового регулирования социально-экономических отношений в строительстве. Отмечено, что современная экономика Украины находится в состоянии хронического кризиса, поэтому интересно проанализировать опыт строительства США, с точки зрения установления нормативно-правового механизма управления социально-экономическими отношениями в строительстве. Обосновано, что в США особенностью государственного управления нормативно-правовым регулированием социально-экономических отношений в строительстве является разработка собственного нормативно-правового механизма и система контроля за обеспечением соблюдения соответствующих требований законодательства. С этой целью принимались соответствующие кодексы, законодательные акты в сфере строительства, в сфере ипотечного кредитования, предоставления льготных кредитов, гарантий, обеспечения действенных механизмов системы страхования и так далее.

Определено, что в большинстве зарубежных стран наблюдается тенденция “приватизации” функций надзора и контроля за выполнением требований строительного законодательства, органов и организаций, ответственных за функционирование системы технического регулирования в строительст- 
ве и так далее. Причины этого - появление более сложных и усовершенствование строительных технологий, увеличение объемов строительства и переход многих стран мира к использованию параметрических норм.

Доказано, что мировой опыт внедрения архитектурно-строительного контроля в зарубежных странах есть необходимой основой для совершенствования национальной государственной системы строительства. Действительно, включение независимых частных специализированных учреждений или экспертов, для выполнения функций контроля не только улучшит качество мер контроля, но и снизит уровень коррупции в строительной сфере.

Ключевые слова: государственное управление, социально-экономические отношения, строительство, нормативно-правовое регулирование, механизм, зарубежный опыт, архитектурно-строительный контроль, нормирование в строительстве.

\section{FEATURES OF LEGAL REGULATION OF SOCIO-ECONOMIC RELATIONS IN CONSTRUCTION: FOREIGN ASPECT}

Abstract. The article reveals the foreign aspect of features of legal regulation of socio-economic relations in construction. It is noted that the modern economy of Ukraine is in a state of chronic crisis, so it is of interest to analyze the construction experience of the United States, Canada and the European Union countries in terms of establishing a regulatory mechanism for managing socioeconomic relations in construction. It substantiates that the feature of the public administration of legal regulation of socio-economic relations in construction in the United States is the development of its own regulatory mechanism and the system of control over compliance with the relevant legal requirements. To this end the adoption of relevant codes, legislative acts in the field of construction, in field of mortgage lending, the provision of soft loans, securities, ensuring effective mechanisms of the insurance system has taken place.

It determines that most foreign countries tend to "privatize" the functions of supervision and control over compliance with the construction legislation, bodies and organizations in charge of the technical regulation system functioning in construction, etc. The reasons for this are the added complexity and improvement of building technologies, the increase in the volume of construction and the transition of many countries to the use of parametric standards (norms).

It is concluded that the international experience in the implementation of architectural and construction control in foreign countries is a necessary foundation for the improvement of the national construction system of a state. The involvement of independent private specialized agencies in the supervision and control system or of experts in performing the functions of control will not only improve the quality of control measures, but also reduce the level of corruption in the construction sector.

Keywords: public administration, socio-economic relations, construction, legal regulation, mechanism, foreign experience, architectural and construction control, standardization in construction. 
Постановка проблеми. Об'єктом правового регулювання різних соціально-економічних відносин у будівництві є, власне, багатогранний процес під назвою “будівництво”, будівельна діяльність та інші види господарської діяльності, що є супутніми у будівництві. Державна політика у галузі будівництва складається із законодавчих, виконавчих та контрольних заходів, а реалізація механізму нормативно-правового регулювання здійснюється шляхом розроблення, прийняття та впровадження нормативно-правових актів і нормативних документів. Одним із основних обов'язкових елементів системи державного управління є функція контролю та нагляду держави 3 питань функціонування будівельного ринку [1, с. 65-66]. В Україні особливе значення має вдосконалення загальних принципів нормативно-правового регулювання будівництва, а отже, видозміна елементів механізму відповідного регулювання. Отже, на сучасному етапі є актуальним дослідження будівельної діяльності як об'єкта регулювання та здійснення всебічного аналізу регуляторних форм нормативно-правового регулювання у цій галузі [2, с. 32].

Аналіз останніх досліджень i публікацій. Питання державного регулювання будівництва в Україні знайшло своє відображення у наукових працях таких вітчизняних вчених: Г. Лиска [5], О. Марушевої [1], О. Непомнящого [6], В. Олюха [3], О. Стукаленка[2], В. Фелікмана [8] та ін. Однак, попри наявні публікації у вітчизняній науці, які присвячених соціально-економічним відносинам будівельної галузі в Україні, питання особливостей нормативно-правового регулювання соціально-економічних відносин в будівництві у зарубіжних країнах та його застосування в українських реаліях досі так і не отримало свого всебічного та комплексного дослідження.

Метою статті є розкриття зарубіжного аспекту особливостей нормативно-правового регулювання соціально-економічних відносин у будівництві.

Виклад основного матеріалу дослідження. Головною метою будівництва $€$ створення кінцевої будівельної продукції, яка може задовольнити потреби як людей, суспільства так і інтереси держави. Тому однією з найголовніших галузей народного господарства у будь-якій країні світу, незалежно від стану іiі економічного розвитку, соціальної спрямованості, політичної стабільності та місця на міжнародній арені, є будівельна галузь, яка, в свою чергу, потребує збалансованої державної політики. Державні заходи мають забезпечити не лише створення сприятливого політичного та економічного клімату для стабільного розвитку будівельного комплексу, але й якість і доступність готової будівельної продукції для кожної людини. Досвід розвинених країн світу свідчить, що ефективне виконання державою своїх функцій дає потужний стимул для розвитку будівництва. Саме тому, доцільно розглянути питання щодо зарубіжного досвіду нормативно-правового регулювання соціально-економічних відносин у будівництві, наголосивши на особливостях державного регулювання 
будівництва у США, Канаді, країнах Європейського Союзу та ін.

Сучасна економіка України перебуває у стані хронічної кризи, тому вбачається слушним проаналізуваних досвід будівництва США з точки зору становлення та розвитку нормативно-правового механізму управління соціально-економічними відносинами у будівництві [3, c. 185]. Враховуючи фактор федеративного устрою, у законодавчій системі США відсутній єдиний нормативно-правовий акт, що регулює відносини у будівництві. Наприклад, процес нормування у будівництві США грунтується на модельних кодексах. Хоча і зберігається невелика кількість адміністративно-територіальних одиниць, в яких продовжують використовуватися будівельні норми, що розроблені самостійно силами відповідних адміністративних органів, але в більшості випадків застосовується практика адаптації модельного законодавства. Будівельні кодекси мають навіть великі міста, наприклад Будівельний кодекс міста Лос-Анджелес або Будівельний кодекс міста Нью-Йорк [4]. Наприклад, метою Будівельного кодексу міста Нью-Йорк є забезпечення розумних мінімальних вимог та стандартів, грунтуючись на сучасних наукових та інженерних знаннях, досвіді та техніці, а також використання сучасних машин, обладнання, матеріалів та форм і методів будівництва, для регулювання будівництва будинків у місті Нью-Йорку в інтересах громадської безпеки, здоров'я, добробуту та збереження навколишнього середовища, а також 3 урахуванням витрат на будівництво та обслуговування будівель [4]. Водночас діють Механічний, Гідравлічний, Житловий, Пожежний кодекси та ін. Ці кодекси визначають стандарти та норми, що встановлюють мінімально допустимий рівень безпеки об’єктів, що конструюються. Особливістю управління нормативно-правовим регулюванням соціально-економічних відносин у будівництві США є наявність Міжнародних кодексів, прийнятих Міжнародною Радою 3 норм та правил (англ. International Code Council) з метою встановлення однакових стандартів виконання будівельних робіт. У цих кодексах містяться стандарти й нормативи виконання будівельних робіт, зокрема, вимоги щодо протипожежної безпеки, проектування, захисту від небезпечних геологічних процесів, забезпечення надійності та конструктивної безпеки будівель, теплових мереж, водопровідно-каналізаційної системи тощо [5, с. 175].

Отже на сьогодні, основні нормативні стандарти, технічні регламенти, сертифікаційні умови, будівельні норми США містяться в Міжнародному будівельному кодексі (англ. International Building Code). Міжнародний будівельний кодекс було розроблено Міжнародною радою 3 норм та правил у 2009 р., він містив положення Національних правил будівництва, Єдиного будівельного кодексу та Кодексу Стандартів США, норми якого стосуються будівництва нових будинків, реконструкції, прибудов, здійснення ремонтних робіт, окрім будівництва одно та двосімейних будинків і таунхаусів до трьох поверхів. Вимоги для даних будівель відповідно регламентують- 
ся Міжнародним житловим кодексом. Міжнародний будівельний кодекс застосовується або прийнятий в 50 штатах, окрузі Колумбія, Гуам, Північних Маріанських островах, Нью-Йорку, Віргінських островах (США) і Пуерто-Ріко. Цікавим є той факт, що оновлення цього кодексу відбувається за розробленим графіком, що заздалегідь публікується на офіційній веб-сторінці Міжнародної Ради $з$ норм та правил. Цей графік містить заходи з обговорення запропонованих змін, бюлетені, звіти, інформацію щодо громадських слухань, обговорення із публікацією відео, охоплюючи весь поточний цикл розробки кодексу. Наразі діючою редакцією кодексу є видання 2018 р. (2018 IBC), проте поточний цикл розробки відповідних актуальних змін включає цикл розробки кодексу на 2018-2019 рр. та заздалегідь відомо, що наступна редакція кодексу буде прийнята у 2021 р. Основними перевагами кодексу є такі: принципи модельного кодексу базуються на охороні здоров'я, безпеці та добробуті населення; кодекс сприяє підвищенню ефективності конструкцій, що забезпечують гнучкість для чиновника, дизайнера, інженера та архітектора; положення кодексу заохочують використання нових та розумніших технологічних досягнень; кодекс підкреслює як регламентаційні, так і інженерні рішення та дозволяє використовувати перевірені часом апробовані методи; кодекс посилається на консенсусні стандарти, що розроблені на національному рівні [6].

США традиційно з 1905 р. делегує функції з нормування у проектуван- ні недержавним організаціям. Так, Національною радою товариств зі страхування від пожежі були випущені Типові будівельні норми і правила, які стали першим будівельним нормативним документом у Сполучених Штатах. На сьогодні, у США функціонують такі недержавні організації, що займаються розробкою i розповсюдженням будівельних норм і стандартів, як: Асоціація фахівців із будівельного нормування, Міжнародна конфедерація фахівців будівельних організацій, Асоціація південних штатів 3 нормування та інші організації. 3 метою узгодження та розвитку єдиної комплексної моделі національних стандартів, що стосуються будівництва, у США у 1994 р. була заснована Міжнародна рада 3 норм і правил як некомерційна організація, яка є офіційною міжнародною організацією зі стандартизації [7].

Показовим та цікавим є досвід США щодо організаційного механізму, з точки зору нагляду та контролю, що супроводжує процес будівництва на всіх етапах. У Сполучених Штатах Америки застосовують багаторівневу систему нагляду та контролю 3 використанням коштів та дотримання законодавчих вимог, де поділ повноважень здійснюється залежно від предмета регулювання між муніципальними інспекціями та державними установами. До основних завдань місцевих та муніципальних органів влади входить забезпечення дотримання мінімальних вимог, встановлених будівельними кодексами щодо охорони здоров'я та безпеки, забезпечення необхідних умов для проживання, праці та відпочинку 
населення тощо [8]. Органами місцевого самоврядування створюється спеціальна установа, що покликана слідкувати за дотриманням положень будівельних кодексів у процесі фінансування проектів будівництва. Зазвичай такою установою є Департаменти у справах будівництва.

У більшості муніципалітетів, департаменти будівництва також відповідають за нагляд та контроль щодо дотримання положень місцевого містобудівного законодавства, зокрема, щодо облаштування населеного пункту, а також процедури ліцензування тощо. Департамент бере участь у перевірці проектних рішень, наданні дозволів на будівництво та огляді будівельних проектів для забезпечення відповідності вимог будівельних норм [3].

Проаналізувавши досвід США можемо виділити такі позитивні моменти:

- кодекси створюють потужний базис у правовому механізмі управління в будівництві;

- створено ефективно сплановану та дієву систему оновлення та винесення до обговорення змін у кодекси;

- організаційний механізм характеризується чітким розподілом влади по вертикалі між вищими та найнижчими органами влади;

- на муніципальному рівні майже всі процедури щодо будівництва проводяться в одній адміністрації (де уповноважені особи підпорядковані одному керівникові);

- існує чіткий горизонтальний розподіл влади між установами та організаціями на одному рівні.
Якщо звертатися до досвіду багатовікової будівельної діяльності можна відзначити, що ризики, пов'язані зі створенням та експлуатацією об'єкта нерухомості, безперечно слід контролювати та зменшувати. У багатьох країнах світу існують системи, які так чи інакше забезпечують безпеку на будівельних майданчиках.

3 початку цього десятиліття, національна стратегія стандартизації діє у США, Великобританії, Німеччині та Франції. За кордоном розробляються і широко використовуються відомі системи управління ризиками, в основі яких лежить безпека продукції. Їх примітною особливістю є застосування принципу запобігання пошкоджень шляхом регулювання праці на всіх етапах. За даними експертів, такий підхід дає змогу зменшити кількість аварій та катастроф за рахунок зменшення витрат на боротьбу з негативними наслідками у 10-15 разів [8].

Доречно зазначити, що у Канаді технічне регулювання будівельної діяльності відбувається на рівні суб'єктів федерації. Зважаючи на те, Канада є країною з різними кліматичними умовами і будівельними традиціями, вважається неприйнятним те, що одні й ті самі будівельні норми застосовуються без урахування місцевих умов. Тому у державі було розроблено так званий новий підхід у нормуванні, сутність якого полягала в тому, щоб провінції та адміністративно-територіальні одиниці мали можливість публікувати окремі документи, що виходять за межі модельних законів, а отже включити до національного кодексу лише 
об'єднані положення, прийняті всіма провінціями та регіонами. Місцеві спеціальні умови та технічні відмінності, що не містяться в основному тексті, мають зазначатися в місцевих додатках до кодексу, який готується для кожного регіону чи провінції та публікується окремо. Новий підхід відіграв головну роль в отриманні вимог модельних кодексів, які можуть відповідати вимогам у канадських провінціях та територіях [8].

Досвід Чехії може бути особливо корисним для України за умови, що система регіонального управління у цій країні функціонує у кризових умовах, аналогічних українським. Вивчаючи досвід державного управління у сфері адміністративної реформи в Чехії, можна підкреслити головний позитивний момент дворівневої структури місцевого самоврядування, створена в Чеській Республіці з 2000 р. [9].

Отже, треба відзначити, що у більшості економічно розвинених країн спостерігається тенденція до “приватизації” функцій розроблення нормативно-правових актів, функцій нагляду та контролю за дотриманням вимог будівельного законодавства, органів та організацій, відповідальних за функціонування системи технічного регулювання у будівництві тощо. Причини цього - ускладнення та вдосконалення будівельних технологій, необхідність залучення організованого громадянського суспільства до розроблення нормативно-правових актів, збільшення обсягів будівництва та перехід багатьох країн світу до використання параметричного методу нормування тощо [8].
Висновки. Вивчення особливостей нормативно-правового регулювання соціально-економічних відносин у будівництві в США, Канаді та країнах Європи свідчить про необхідність систематичного поєднання методів державного управління 3 урахуванням імплементації елементів успішного досвіду іноземних країн та застосування кращих світових практик, адаптація законодавства Європейського Союзу шляхом створення відповідних процедур та механізмів, а також впровадження європейських адміністративних принципів. Метою Закону України "Про внесення змін до деяких законодавчих актів України щодо децентралізації повноважень у сфері архітектурно-будівельного контролю та удосконалення містобудівного законодавства" є реалізація європейського принципу децентралізації влади у галузі будівництва, особливо завдяки розширенню різноманіття державних архітектурно-будівельних органів контролю та інспекції.

Обгрунтовано, що особливістю державного управління нормативно-правовим регулюванням соціально-економічних відносин у будівництві у США $є$ розробка власного нормативно-правового механізму та система контролю за дотриманням відповідних законодавчих вимог. Модельні кодекси США створюють потужний базис у правовому механізмі управління в будівництві.

Визначено, що оновлення Міжнародного будівельного кодексу, що діє на території більшості штатів у США, відбувається за розробленим графіком, що заздалегідь публікується на офіційній веб-сторінці Ради 
3 міжнародних кодексів. Цей графік містить заходи з обговорення запропонованих змін, бюлетені, звіти громадських слухання, обговорення із публікацією відео, охоплюючи поточний цикл розробки кодексу. Таким чином створено ефективно сплановану та дієву систему своєчасного оновлення та винесення до обговорення змін у кодекси. Варто звернути увагу на планування законотворчої діяльності за аналогічними принципами та підходами в українських реаліях.

Визначено, що у більшості зарубіжних країн спостерігається тенденція до “приватизаціі” функцій нагляду та контролю за дотриманням вимог будівельного законодавства, органів та організацій, відповідальних за функціонування системи технічного регулювання у будівництві тощо. Причинами цього є ускладнення та вдосконалення будівельних технологій, збільшення обсягів будівництва та перехід багатьох країн світу до використання параметричних норм.

\section{СПИСОК ВИКОРИСТАНИХ ДЖЕРЕЛ}

1. Марушева О.А. Тенденції нормативно-правового регулювання соціально-економічних відносин у будівництві в країнах розвинутої демократії / О. А. Марушева // Актуальні проблеми державного управління. № 1 (55). С. 63-68.

2. Стукаленко О. В. Теоретичні засади державного контролю та нагляду в сфері будівельної діяльності / О. В. Стукаленко // Правова держава. 2014. № 17. 135 c.
3. Олюха В. Г. Оптимізація капітального будівництва: господарсько-правові проблеми: монографія. К.: Центр учб. л-ри, 2015. 302 с.

4. New York City Building: Code. 2014 [Електронний ресурс]. - Режим доступу: https://www1.nyc.gov/site/ buildings/codes/2014-constructioncodes.page\#bldgs

5. Лиско Г. О. Процедура отримання дозволу на будівництво: досвід Сполучених Штатів Америки // Наук. вісн. Львів. держ. ун-ту внутрішніх справ. 2012. № 4. С. 175.

6. Overview of the International Building Code [Electronic resource]. Access mode: Overview of the International Building Code [Electronic resource]. Access mode: https://www. iccsafe.org/products-and-services/icodes/2018-i-codes/ibc/

7. Непомнящий О. М. Децентралізація державного регулювання будівельної діяльності: закордонний досвід для України / О. М. Непомнящий // Державне будівництво. 2014. № 1 [Електронний ресурс]. Режим доступу: http://nbuv.gov.ua/UJRN/ DeBu_2014_1_30

8. Серых A. Техеническое регулирование в строительстве. Аналитический обзор мирового опыта: Snip Innovative Technologies; рук / A. Серых. Чикаго: SNIP, 2010. 889 c.

9. Система державного управління Республіки Чехія: досвід для України / уклад. Х. М. Дейнега ; за заг. ред. Ю. В. Ковбасюка, С. В. Загороднюка. К. : НАДУ, 2011. 40 с.

\section{REFERENCES}

1. Marusheva O. A. (2019). Tendentsii normatyvno-pravovoho rehuliuvannia sotsialno-ekonomichnykh vidnosyn $\mathrm{u}$ budivnytstvi $\mathrm{v}$ krainakh rozvynu- 
toi demokratii [Trends in regulatory regulation of socio-economic relations in construction in developed democracies]. Aktualni problemy derzhavnoho upravlinnia - Actual problems of public administration, 1 (55), 63-68 [in Ukrainian].

2. Stukalenko O. V. (2014). Teoretychni zasady derzhavnoho kontroliu ta nahliadu v sferi budivelnoi diialnosti [Theoretical foundations of state control and supervision in the field of construction activity]. Pravova derzhava - Legal State, 17, 32-38 [in Ukrainian].

3. Oliukha V. H. (2015). Optymizatsiia kapitalnoho budivnytstva: hospodarsko-pravovi problemy [Optimization of capital construction: economic and legal problems]. Kyiv: Tsentr uchbovoi literatury [in Ukrainian].

4. New York City Building: Code. (2014). wrow1.nyc.gov. Retrieved from https://www1.nyc.gov/site/buildings/codes/2014-construction-codes. page\#bldgs [in English].

5. Lysko H. O. (2012). Protsedura otrymannia dozvolu na budivnytstvo: dosvid Spoluchenykh Shtativ Ameryky [Building Permit Procedure: United States Experience]. Naukovyi visnyk Lvivskoho derzhavnoho universytetu vnutrishnikh sprav - Bulletin of the Lviv State University of Internal Affairs, 4, 174-183 [in Ukrainian].

6. Overview of the International Building Code. (2018). wroro.iccsafe.org. Retrieved from https://www.iccsafe.org/ products-and-services/i-codes/2018-icodes/ibc/ [in English].

7. Nepomniashchyi O. M.(2014). Detsentralizatsiia derzhavnoho rehuliuvannia budivelnoi diialnosti: zakordonnyi dosvid dlia Ukrainy [Decentralization of state regulation of construction activity: foreign experience for Ukraine]. Derzhavne budivnytstoo - State building, 1. Retrieved from http://nbuv. gov.ua/UJRN/DeBu_2014_1_30 [in Ukrainian].

8. Serykh A. (2010). Tekhnicheskoe regulirovanie v stroitelstve. Analiticheskiy obzor mirovogo opyta: Snip Innovative Technologies [Technical regulation in construction. An analytical review of world experience: Snip Innovative Technologies]. Chikago: SNIP [in Russian].

9. Deineha Kh. M., Kovbasiuk Yu. V., Zahorodniuk S. V. (Eds.). (2011). Systema derzhavnoho upravlinnia Respubliky Chekhiia: dosvid dlia Ukrainy [The system of the sovereign government of Czech Republic]. Kyiv: NADU [in Ukrainian]. 